\title{
Selective Inhibition of Viral RNA Transcription by Skyrin*
}

\author{
Yoshikazu Yanagi, ${ }^{* *}$ Masanobu Nakata and Naoji Suzuki \\ Faculty of Agriculture, Kobe University, Rokkodai, Nada-ku, Kobe 657, Japan
}

(Received October 7, 1975)

\begin{abstract}
Three structurally related pigments, rugulosin (Rug) and skyrin (Sky) which are products of Endothia parasitica, and luteoskyrin (Lut) which is a well-known mycotoxin produced by Penicillium islandicum, were tested for their inhibitory effects on rice dwarf virus (RDV) RNA transcription and E. coli DNA-dependent RNA polymerase activities, using in vitro assay systems for both enzymes. Lut inhibits only $E$. coli RNA polymerase but has no effect on RDV-RNA transcriptase. Rug strongly inhibits E. coli RNA polymerase but weakly RDV-RNA transcriptase. Conversely, Sky inhibits RDV-RNA transcriptase without inhibiting E. coli RNA polymerase. The $\mathrm{Mg}^{2+}$-mediated complex formation of Lut and Rug with DNA and that of Rug with RDV-RNA may account for their inhibitory effects on both enzymes, however this is not true with Sky on DNA and Sky on RDV-RNA. Sky forms complex with $\mathrm{Mg}^{2+}$ because its absorption spectrum shifts to longer wave lengths with increasing amounts of $\mathrm{Mg}^{2+}$ added but the complex does not form floccules which can be seen in Lut- $\mathrm{Mg}^{2+}$ and Rug- $\mathrm{Mg}^{2+}$ mixtures. Sky-Mg-DNA and Sky-Mg-RDV-RNA mixtures do not form such a complex which can be precipitated by centrifugation at $59,000 \times g$ for $20 \mathrm{~min}$. Sephadex G-25 column chromatography of the mixtures indicates that nucleic acids are completely separated from Sky-Mg complex. When RDV-virions are pretreated with Sky and $\mathrm{Mg}^{2+}$, pelleted by centrifugation, then added to the reaction mixture, RDV-RNA transcriptase is not inhibited at all, whereas inhibited strongly by the addition of the supernatant which contains Sky. These results suggest that Sky inhibits RDV-RNA transcriptase not by its direct action to RDV-RNA present in virions but by its contact with virions at the site of transcription.
\end{abstract}

\section{INTRODUCTION}

In a series of studies on rice dwarf virus, we have attempted to find out some agents which inhibit the synthesis of viral RNA without inhibiting the syntheses of host cell nucleic acids. Rice dwarf virus (RDV) virions contain double-stranded RNA (dsRNA) ${ }^{1)}$ and its transcriptase. ${ }^{2}$ The dsRNA can easily be separated quantitatively from cell nucleic acids in RDV-infected leaves of rice plants by using chromatographic techniques. ${ }^{3}$ ) This enabled us to make a screening test for some agents which inhibit ${ }^{32} \mathrm{P}$-incorporation into viral dsRNA but not inhibit the incorpora-

* Screening of Chemotherapeutants for Rice Dwarf Virus (Part III)

** Present address: Rohm and Haas, Asia, Azabudai, Minato-ku, Tokyo tion into ribosomal RNA. The result indicated that cycloheximide inhibited ${ }^{32} \mathrm{P}$-incorporation into both RDV-RNA and ribosomal RNA suggesting that the antibiotic might be phytotoxic and this was actually true. Blasticidin S and kasugamycin were not enough inhibitory on ${ }^{32} \mathrm{P}$-incorporation into RDV-RNA but rather stimulating ${ }^{32} \mathrm{P}-$ incorporation into ribosomal RNA. ${ }^{4}$ Second step of screening was directed to select some agents which inhibit RDV-RNA transcriptase without inhibiting $E$. coli DNA-dependent RNA polymerase, using in vitro assay systems for both enzymes. Acridine orange, ethidium bromide, methylene blue, azure $B$, azure $A$, azure $\mathrm{C}$ and thionine inhibited both enzymes almost equally. Chloroquine, quinacrine, luteoskyrin, actinomycin D and rifamycin SV inhibited only $E$. coli RNA polymerase but 
had no effect on RDV-RNA transcriptase. ${ }^{5)}$ Some of the agents in the first group were known to catalyze photodynamic degradation of nucleic acids, ${ }^{6,7)}$ and this was also the case with methylene blue and azure $B$ on RDV-RNA, causing loss of guanine in RDVRNA. ${ }^{5)}$ Among these dyes and drugs, only azure B stimulates the elongation of RDVinfected rice plants when applied to the culture solution at $3-6 \mathrm{ppm}{ }^{8}{ }^{8}$ It was suggested that the safe application of azure $B$ without causing any phytotoxicity might be due to its in vivo affinity particularly to inclusion bodies but not to nuclei. ${ }^{5}$ ) In fact, azure B stains inclusion bodies without staining nuclei at least in living leaf tissues.

This paper reports the results of comparison of the structurally related three pigments, luteoskyrin, rugulosin and skyrin on RDVRNA transcriptase and E. coli DNA-dependent RNA polymerase and the fact that skyrin inhibits RDV-RNA transcriptase without inhibiting E. coli RNA polymerase.

\section{MATERIALS AND METHODS}

Host plant, insect vector and virus isolate: Seedlings of rice plant (Norin-8) were inoculated at 3-leaf stage by viruliferous leafhoppers, Nephotettix cincticeps Uhl., which had been reared on RDV-infected rice plants. The virus isolate and the insect colony used in this study are the same as previously reported. ${ }^{2)}$

Preparation of RDV: The method of purification was essentially as described by Kimura. ${ }^{9)}$ Hundred $g$ of leaves of infected rice plants were cut into small pieces, homogenized in $300 \mathrm{ml}$ of $0.1 \mathrm{M}$ phosphate buffer (PB), $\mathrm{pH} 6.8$, and $100 \mathrm{ml}$ of carbontetrachloride using a Vir-Tis homogenizer under icecooling. The homogenate was centrifuged at $3,000 \mathrm{rpm}$ for $10 \mathrm{~min}$. The supernatant was mixed with polyethylene glycol $(6,500)$ and $\mathrm{NaCl}$ to final concentrations of $6 \%$ and $0.3 \mathrm{M}$ respectively and incubated at $4^{\circ} \mathrm{C}$ for $3 \mathrm{hr}$. The mixture was centrifuged at $9,500 \times g$ for $1 \mathrm{hr}$ and the precipitate was suspended in $20 \mathrm{ml}$ of PB. The suspension was added with half volume of fluorocarbon (Daifron S3), stirred vigorously and centrifuged at $3,000 \mathrm{rpm}$ for $10 \mathrm{~min}$. The supernatant was layered on a sucrose density gradient consisting of $10 \mathrm{ml}$ each of 20 and $30 \%$ solutions, and centrifuged at $24,000 \mathrm{rpm}$ for $1 \mathrm{hr}$ using Hitachi RPS- 25 rotor. The bottom band was separated, layered on a sucrose density gradient consisting of $10 \mathrm{ml}$ each of 30 and $40 \%$ solutions, then centrifuged at $24,000 \mathrm{rpm}$ for $1 \mathrm{hr}$. The bottom band was separated, dialyzed against $0.1 \mathrm{~m}$ acetate buffer, $\mathrm{pH} 6.0$, overnight, then centrifuged at $24,000 \mathrm{rpm}$ for $1 \mathrm{hr}$. The pellet was resuspended in a small amount of acetate buffer and used as purified RDV preparation.

Preparation of RDV-RNA: dsRDV-RNA was prepared from the purified RDV preparation by the.cold-phenol method as described by Miura $e t$ al. ${ }^{1)}$ The RNA was usually stored in $67 \%$ ethanol at $-20^{\circ} \mathrm{C}$ until use.

Preparation of E. coli DNA: E. coli DNA was prepared by Marmur's method. ${ }^{10)}$

Assay of RDV-RNA transcriptase activity: The standard reaction mixture for assay of RDV-RNA transcriptase activity contained in a final volume of $0.25 \mathrm{ml}$ :

ATP, GTP, CTP, UTP $0.2 \mu$ moles each

$\begin{array}{ll}{ }^{3} \mathrm{H} \text {-UTP } & 2.0 \mu \mathrm{Ci} \\ \mathrm{MgCl}_{2} & 2.0 \mu \mathrm{moles} \\ \text { phosphoenol pyruvate } & 1.0 \mu \mathrm{moles} \\ \text { pyruvate kinase } & 25 \mu \mathrm{g} \\ \text { chymotrypsin } & 50 \mu \mathrm{g} \\ \text { Tris- } \mathrm{HCl}, \mathrm{pH} 8.5 & 25 \mu \mathrm{moles} \\ \text { RDV } & 200 \mu \mathrm{g} \\ & (0.08 \mu \text { moles of } \mathrm{P})\end{array}$

After incubation at $35^{\circ} \mathrm{C}$ for $60 \mathrm{~min}$ the reaction was stopped by adding $3 \mathrm{ml}$ of icecold 5\% trichloroacetic acid (TCA) containing $0.02 \mathrm{M}$ sodium pyrophosphate (NaPP). The precipitates were collected on Schleicher and Schuell membrane filters $(0.45 \mu \mathrm{m}$ poresize) and washed with $20 \mathrm{ml}$ of $5 \%$ TCA containing $\mathrm{NaPP}$, and then with $95 \%$ ethyl alcohol. The filters were placed in scintilation vials, dried, and the radioactivity was determined by liquid scintillation spectrometry.

Assay of E. coli DNA-dependent RNA polymerase activity: The standard reaction mixture for assay of $E$. coli RNA polymerase contained in a final volume of $0.25 \mathrm{ml}$ :

ATP, GTP, CTP, UTP $0.1 \mu$ moles each ${ }^{3} \mathrm{H}$-UTP $\quad 2.0 \mu \mathrm{Ci}$ 


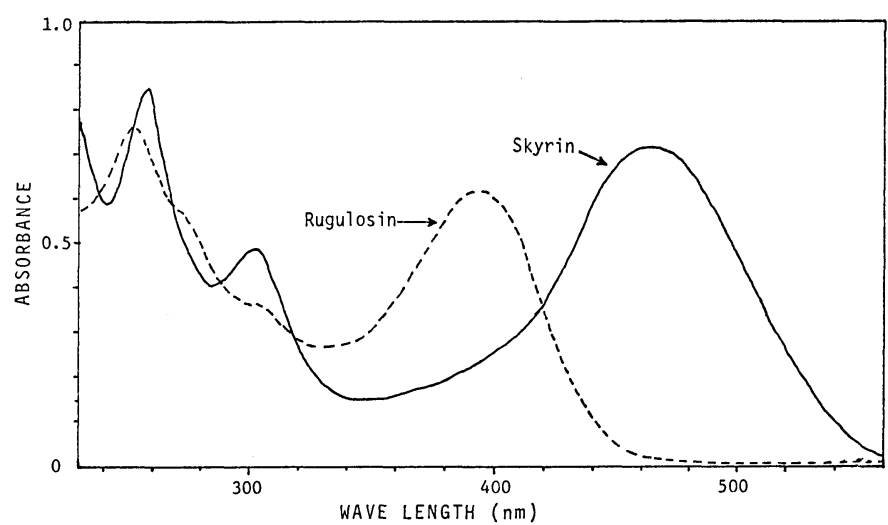

Fig. 1 Absorption spectra of skyrin (-) and rugulosin $(-. .-$.$) in ethanol.$

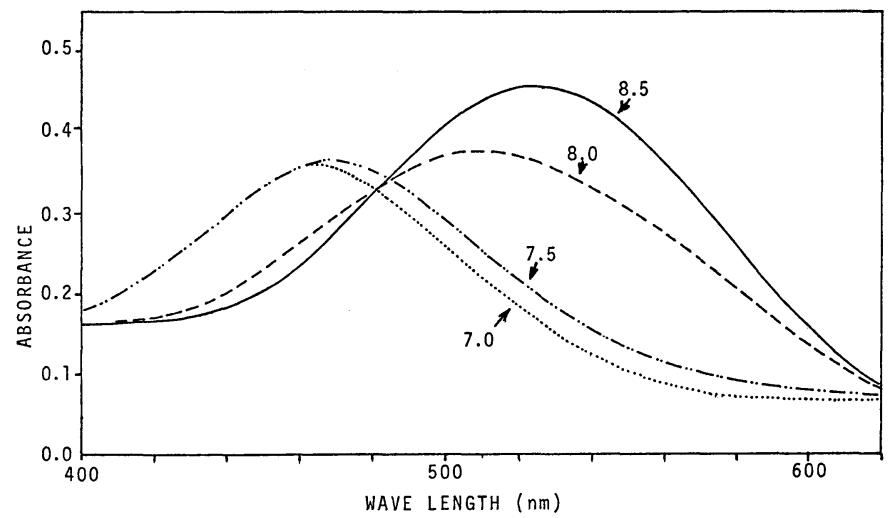

Fig. 2 Shift of absorption spectrum skyrin with varying $\mathrm{pH}$ 's.

magnesium acetate manganese sulfate mercaptoethanol Tris- $\mathrm{HCl}, \mathrm{pH} 7.8$ E. coli DNA

$1.25 \mu$ moles

$0.5 \mu$ moles

$1.25 \mu$ moles

$30 \mu$ moles

$24 \mu \mathrm{g}$

$(0.08 \mu$ moles of $\mathrm{P})$

E. coli RNA polymerase 0.5 unit

(Boeringer-Mannheim Co.)

After incubating at $37^{\circ} \mathrm{C}$ for $60 \mathrm{~min}$, the reaction was stopped by adding $3 \mathrm{ml}$ of cold TCA containing $0.02 \mathrm{M}$ NaPP. The procedure for counting radioactivity was as described above.

Extraction of rugulosin and skyrin from mycelial mat of Endothia parasitica: Luteoskyrin was kindly furnished by Dr. H. Kurata, National Hygenic Institute. Methods for the extraction and purification of rugulosin and skyrin from mycelial mats of Endothia parasitica were the same as described by Shibata et al. ${ }^{11-14)}$ Absorption spectra of rugulosin and skyrin were shown in Fig. 1. Shift of absorption spectrum of skyrin with varying pH's is shown in Fig. 2.

\section{RESULTS}

1. Comparison of Inhibitory Effects of Three Pigments on E. coli RNA Polymerase and $R D V-R N A$ Transcriptase

Luteoskyrin (Lut), rugulosin (Lut) and skyrin (Sky) were dissolved in minimum amounts of $0.2 \mathrm{~N} \mathrm{Na}_{2} \mathrm{CO}_{3}$, diluted with water and the $\mathrm{pH}$ was adjusted to 7.8 for $E$. coli RNA polymerase assay system and to 8.5 for RDVRNA transcriptase assay system. These were added to both assay systems at $P / D$ ratios of $10 / 2$ and $10 / 4$, where $P$ is moles of phosphorus in nucleic acids, 0.08 $\mu$ moles in each $0.25 \mathrm{ml}$ of reaction mixture, and $D$ is moles of pigments, 0.016 and 0.032 $\mu$ moles for $10 / 2$ and $10 / 4$ ratios respectively. Inhibitory effects of three pigments are shown in Table 1.

Results indicate that Lut inhibits $E$. coli RNA polymerase only and Rug inhibits both $E$. coli RNA polymerase and RDV-RNA transcriptase, whereas Sky inhibits RDV-RNA transcriptase without in-

Table 1 Comparison of inhibitory effects of luteoskyrin, rugulosin and skyrin on $E$. coli DNA-dependent RNA polymerase and RDV-RNA transcriptase.

\begin{tabular}{lccc}
\hline \multirow{2}{*}{ Inhibitor } & $\begin{array}{c}P / D \\
\text { ratio }\end{array}$ & \multicolumn{2}{c}{$\begin{array}{c}\text { Percent inhibition } \\
\text { Transcription of }\end{array}$} \\
\cline { 3 - 4 } & & $E$. coli DNA & RDV-RNA \\
\hline Luteoskyrin & $10: 2$ & 64 & 0 \\
& $10: 4$ & 85 & 0 \\
Rugulosin & $10: 2$ & 62 & 14 \\
& $10: 4$ & 66 & 27 \\
Skyrin & $10: 2$ & 0 & 36 \\
& $10: 4$ & 4 & 61
\end{tabular}

Numbers in the table are the average of four repetitions. 
Table 2 Effect of $\mathrm{Mg}^{2+}$ concentrations on RDVRNA transcriptase activity.

\begin{tabular}{crr}
\hline $\begin{array}{c}\mathrm{MgCl}_{2} \\
\left(\mu \mathrm{mole}^{*}\right)\end{array}$ & $\begin{array}{c}{ }^{3} \mathrm{H} \text {-UMP incorporated into } \\
\text { TCA-insol. RNA (CPM) }\end{array}$ & $\%$ \\
\hline 0 & 691 & 3 \\
0.5 & 9,328 & 40 \\
1.0 & 22,274 & 97 \\
2.0 & 23,081 & 100 \\
3.0 & 15,629 & 68 \\
4.0 & 9,073 & 39 \\
6.0 & 3,646 & 16 \\
9.0 & 1,250 & 5 \\
12.0 & 869 & 4 \\
\hline
\end{tabular}

* $\mu$ moles in $0.25 \mathrm{ml}$ of standard reaction mixture.

hibiting E. coli RNA polymerase.

2. Complex Formation of E. coli DNA and $R D V-R N A$ with Pigments in the Presence of $\mathrm{Mg}^{2+}$

$\mathrm{Mg}^{2+}$ is essential for the in vitro syntheses of RNA directed by E. coli DNA and RDVRNA. Optimum concentration of $\mathrm{Mg}^{2+}$ in the reaction mixture for RDV-RNA transcriptase lies in the range from 1.0 to 2.0 $\mu$ moles $/ 0.25 \mathrm{ml}(4-8 \mathrm{~mm}$ ) (Table 2 ). In the ranges below 0.5 and above $4.0 \mu$ moles the rate of transcription is markedly suppressed. This fact means that $\mathrm{Mg}^{2+}$ is always present in the reaction mixtures where pigments interact with DNA or RDV-RNA. It has been reported that Lut forms complex with DNA in the presence of $\mathrm{Mg}^{2+}$, the molar ratio of $\mathrm{DNA} / \mathrm{Mg} / \mathrm{Lut}$ being $4-6: 1: 1$ and that Lut forms complexes with poly-U and poly-C in the presence of $\mathrm{Mg}^{2+}$ with $1: 1: 1$ ratio. ${ }^{15-17)}$ Questions arise as to whether or not other two pigments form complexes with DNA and RDV-RNA in the presence of $\mathrm{Mg}^{2+}$.

The lowest lines in Table 3 and 4 show that $\mathrm{OD}_{260}$ values of $E$. coli $\mathrm{DNA}$ and RDVRNA dissolved in $0.1 \mathrm{~m}$ Tris- $\mathrm{HCl}, \mathrm{pH} 8.5$, containing $\mathrm{Mg}^{2+}$, decrease by about $10 \%$ after $20 \mathrm{hr}$ incubation at room temperature and subsequent centrifugation at $59,000 \times g$ for $20 \mathrm{~min}$. This $10 \%$ decrease of $\mathrm{OD}_{260}$ value was taken into account for reading the data shown in Tables 3 and 4 .

Table 3 indicates that Lut and Rug produce floccules immediately after addition of
Table 3 Effects of $\mathrm{Mg}^{2+}$ on the sedimentation of DNA-luteoskyrin, DNA-rugulosin and DNA-skyrin mixtures.

\begin{tabular}{|c|c|c|c|}
\hline & & $\begin{array}{l}\text { Before } \\
\text { centrif. }\end{array}$ & $\begin{array}{l}\text { After } \\
\text { centrif. }\end{array}$ \\
\hline Luteoskyrin & $\begin{array}{l}\mathrm{OD}_{450} \\
\mathrm{OD}_{260}\end{array}$ & $\begin{array}{l}0.22 \\
0.32\end{array}$ & $\begin{array}{l}0.20 \\
0.30\end{array}$ \\
\hline Lut. $+\mathrm{MgCl}_{2}$ & $\begin{array}{l}\mathrm{OD}_{450} \\
\mathrm{OD}_{260}\end{array}$ & floccul. & $\begin{array}{l}0.05 \\
0.10\end{array}$ \\
\hline Lut.+ DNA & $\begin{array}{l}\mathrm{OD}_{450} \\
\mathrm{OD}_{260}\end{array}$ & $\begin{array}{l}0.24 \\
1.30\end{array}$ & $\begin{array}{l}0.10 \\
1.00\end{array}$ \\
\hline Lut. $+\mathrm{MgCl}_{2}+\mathrm{DNA}$ & $\begin{array}{l}\mathrm{OD}_{450} \\
\mathrm{OD}_{260}\end{array}$ & $\begin{array}{l}0.24 \\
1.25\end{array}$ & $\begin{array}{l}0.09 \\
0.89\end{array}$ \\
\hline Rugurosin & $\begin{array}{l}\mathrm{OD}_{420} \\
\mathrm{OD}_{260}\end{array}$ & $\begin{array}{l}0.37 \\
0.40\end{array}$ & $\begin{array}{l}0.37 \\
0.40\end{array}$ \\
\hline Rug. $+\mathrm{MgCl}_{2}$ & $\begin{array}{l}\mathrm{OD}_{420} \\
\mathrm{OD}_{260}\end{array}$ & floccul. & $\begin{array}{l}0.10 \\
0.15\end{array}$ \\
\hline Rug. + DNA & $\begin{array}{l}\mathrm{OD}_{420} \\
\mathrm{OD}_{260}\end{array}$ & $\begin{array}{l}0.37 \\
1.45\end{array}$ & $\begin{array}{l}0.36 \\
1.35\end{array}$ \\
\hline Rug. $+\mathrm{MgCl}_{2}+\mathrm{DNA}$ & $\begin{array}{l}\mathrm{OD}_{420} \\
\mathrm{OD}_{260}\end{array}$ & $\begin{array}{l}0.43 \\
1.40\end{array}$ & $\begin{array}{l}0.20 \\
0.69\end{array}$ \\
\hline Skyrin & $\begin{array}{l}\mathrm{OD}_{530} \\
\mathrm{OD}_{260}\end{array}$ & $\begin{array}{l}0.12 \\
0.29\end{array}$ & $\begin{array}{l}0.12 \\
0.28\end{array}$ \\
\hline Sky. $+\mathrm{MgCl}_{2}$ & $\begin{array}{l}\mathrm{OD}_{530} \\
\mathrm{OD}_{260}\end{array}$ & $\begin{array}{l}0.12 \\
0.30\end{array}$ & $\begin{array}{l}0.12 \\
0.28\end{array}$ \\
\hline Sky.+DNA & $\begin{array}{l}\mathrm{OD}_{530} \\
\mathrm{OD}_{260}\end{array}$ & $\begin{array}{l}0.11 \\
1.35\end{array}$ & $\begin{array}{l}0.10 \\
1.20\end{array}$ \\
\hline Sky. $+\mathrm{MgCl}_{2}+\mathrm{DNA}$ & $\begin{array}{l}\mathrm{OD}_{530} \\
\mathrm{OD}_{260}\end{array}$ & $\begin{array}{l}0.13 \\
1.30\end{array}$ & $\begin{array}{l}0.12 \\
1.15\end{array}$ \\
\hline E. coli $\mathrm{DNA}+\mathrm{MgCl}_{2}$ & $\mathrm{OD}_{260}$ & 1.06 & 0.95 \\
\hline
\end{tabular}

Each mixture contains $0.53 \mu \mathrm{mol}$. of E. coli DNA (P), one of the pigments $(0.07 \mu \mathrm{mol}$. of luteoskyrin, $0.074 \mu \mathrm{mol}$. of rugulosin or $0.073 \mu \mathrm{mol}$. of skyrin) and $1.0 \mu \mathrm{mol}$. of $\mathrm{MgCl}_{2}$ in $3.5 \mathrm{ml}$ of $0.1 \mathrm{M}$ Tris- $\mathrm{HCl}, \mathrm{pH} 8.5$. After $20 \mathrm{hr}$ incubation at room temperature, the mixtures were centrifuged for $20 \mathrm{~min}$ at $30,000 \mathrm{rpm}$ in Hitachi RP-40 rotor.

$\mathrm{Mg}^{2+}$, whereas Sky does not. The production of floccules of $\mathrm{Lut}-\mathrm{Mg}$ and Rug- $\mathrm{Mg}$ complexes is inhibited by the presence of $E$. coli DNA. After $20 \mathrm{hr}$-incubation at room temperature, Lut-Mg-DNA and Rug-MgDNA complexes are precipitated by centrifugation at $59,000 \times g$ for $20 \mathrm{~min}$, resulting in the decrease of $\mathrm{OD}_{260}$ values of the supernatants. Nothing is precipitated from the mixture of Sky-Mg-DNA.

Table 4 indicates that the presence of RDV-RNA also inhibits that production of floccules which are to be produced in Lut$\mathrm{Mg}$ and Rug-Mg mixtures. Precipitation of pigment-Mg-RDV-RNA complex after $20 \mathrm{hr}-$ incubation and subsequent centrifugation oc- 
Table 4 Effects of $\mathrm{Mg}^{2+}$ on the sedimentation of RDV-RNA-luteoskyrin, RDV-RNArugulosin and RDV-RNA-skyrin mixtures.

\begin{tabular}{|c|c|c|c|}
\hline & & $\begin{array}{l}\text { Before } \\
\text { centrif. }\end{array}$ & $\begin{array}{l}\text { After } \\
\text { centrif. }\end{array}$ \\
\hline Luteoskyrin & $\begin{array}{l}\mathrm{OD}_{450} \\
\mathrm{OD}_{260}\end{array}$ & $\begin{array}{l}0.22 \\
0.32\end{array}$ & $\begin{array}{l}0.20 \\
0.30\end{array}$ \\
\hline Lut. $+\mathrm{MgCl}_{2}$ & $\begin{array}{l}\mathrm{OD}_{450} \\
\mathrm{OD}_{260}\end{array}$ & floccul. & $\begin{array}{l}0.05 \\
0.10\end{array}$ \\
\hline Lut. + RDV-RNA & $\begin{array}{l}\mathrm{OD}_{450} \\
\mathrm{OD}_{260}\end{array}$ & $\begin{array}{l}0.24 \\
1.24\end{array}$ & $\begin{array}{l}0.22 \\
1.05\end{array}$ \\
\hline Lut. $+\mathrm{MgCl}_{2}+\mathrm{RDV}-\mathrm{RNA}$ & $\begin{array}{l}\mathrm{OD}_{450} \\
\mathrm{OD}_{260}\end{array}$ & $\begin{array}{l}0.23 \\
1.17\end{array}$ & $\begin{array}{l}0.10 \\
1.05\end{array}$ \\
\hline Rugulosin & $\begin{array}{l}\mathrm{OD}_{420} \\
\mathrm{OD}_{260}\end{array}$ & $\begin{array}{l}0.37 \\
0.40\end{array}$ & $\begin{array}{l}0.37 \\
0.40\end{array}$ \\
\hline Rug. $+\mathrm{MgCl}_{2}$ & $\begin{array}{l}\mathrm{OD}_{420} \\
\mathrm{OD}_{260}\end{array}$ & floccul. & $\begin{array}{l}0.10 \\
0.15\end{array}$ \\
\hline Rug.+RDV-RNA & $\begin{array}{l}\mathrm{OD}_{420} \\
\mathrm{OD}_{260}\end{array}$ & $\begin{array}{l}0.36 \\
1.33\end{array}$ & $\begin{array}{l}0.36 \\
1.33\end{array}$ \\
\hline Rug. $+\mathrm{MgCl}_{2}+\mathrm{RDV}-\mathrm{RNA}$ & $\begin{array}{l}\mathrm{OD}_{420} \\
\mathrm{OD}_{260}\end{array}$ & $\begin{array}{l}0.40 \\
1.29\end{array}$ & $\begin{array}{l}0.10 \\
1.00\end{array}$ \\
\hline Skyrin & $\begin{array}{l}\mathrm{OD}_{530} \\
\mathrm{OD}_{260}\end{array}$ & $\begin{array}{l}0.12 \\
0.29\end{array}$ & $\begin{array}{l}0.12 \\
0.28\end{array}$ \\
\hline $\mathrm{Sky} \cdot+\mathrm{MgCl}_{2}$ & $\begin{array}{l}\mathrm{OD}_{530} \\
\mathrm{OD}_{260}\end{array}$ & $\begin{array}{l}0.12 \\
0.30\end{array}$ & $\begin{array}{l}0.12 \\
0.28\end{array}$ \\
\hline Sky.+RDV-RNA & $\begin{array}{l}\mathrm{OD}_{530} \\
\mathrm{OD}_{260}\end{array}$ & $\begin{array}{l}0.11 \\
1.19\end{array}$ & $\begin{array}{l}0.11 \\
1.07\end{array}$ \\
\hline Sky. $+\mathrm{MgCl}_{2}+\mathrm{RDV}-\mathrm{RNA}$ & $\begin{array}{l}\mathrm{OD}_{530} \\
\mathrm{OD}_{260}\end{array}$ & $\begin{array}{l}0.11 \\
1.18\end{array}$ & $\begin{array}{l}0.11 \\
1.05\end{array}$ \\
\hline $\mathrm{RDV}-\mathrm{RNA}+\mathrm{MgCl}_{2}$ & $\mathrm{OD}_{260}$ & 1.03 & 0.93 \\
\hline
\end{tabular}

The mixture contains $0.51 \mu \mathrm{mol}$. of RDV-RNA (P) in $3.5 \mathrm{ml}$.
Table 5 Effect of pretreatment of RDV-virions with skyrin on RDV-RNA transcriptase.

\begin{tabular}{|c|c|c|c|c|}
\hline & Treatment & CPM & $\begin{array}{c}\% \\
\text { Loss }\end{array}$ & $\begin{array}{c}\% \\
\text { Inhibition }\end{array}$ \\
\hline (1) & $\begin{array}{l}\text { Preincubation of virions } \\
\text { at } \mathrm{pH} 8.5,35^{\circ} \mathrm{C}, 60 \mathrm{~min}\end{array}$ & 25,379 & 38 & - \\
\hline (2) & $\begin{array}{l}\text { Preincubation of virions } \\
\text { with Sky, } \mathrm{pH} 8.5,35^{\circ} \mathrm{C} \text {, } \\
60 \mathrm{~min}\end{array}$ & 30,356 & & 0 \\
\hline (3) & $\begin{array}{l}\text { Virions in }(1)+ \\
\text { Supernatant }(2)\end{array}$ & 458 & & 88 \\
\hline (4) & $\begin{array}{l}\text { Control (virions are } \\
\text { added to reaction mix- } \\
\text { ture without preincuba- } \\
\text { tion) }\end{array}$ & 41,113 & & 一 \\
\hline (5) & $\begin{array}{l}\text { (4) }+ \text { Sky at } P / D \text { ratio } \\
\text { of } 10: 4\end{array}$ & 1,979 & & 95 \\
\hline (6) & $\begin{array}{l}\text { (4) }+ \text { Sky at } P / D \text { ratio } \\
\text { of } 10: 2\end{array}$ & 6,519 & & 84 \\
\hline (7) & $\begin{array}{l}\text { (4) }+ \text { Sky at } P / D \text { ratio } \\
\text { of } 10: 1\end{array}$ & 34,364 & & 16 \\
\hline
\end{tabular}

(1) Virions (2 $\mathrm{mg}$ ) were incubated in incubation mixture $(2.5 \mathrm{ml})$ containing $250 \mu$ moles of Tris- $\mathrm{HCl}(\mathrm{pH} 8.5)$ and $20 \mu$ moles of $\mathrm{MgCl}_{2}$. After incubation $200 \mu \mathrm{g}$ of virions were taken into reaction mixture.

(2) Virions (2 mg) were incubated in incubation mixture $(2.5 \mathrm{ml})$ containing $250 \mu$ moles of Tris- $\mathrm{HCl}(\mathrm{pH} 8.5), 20 \mu$ moles of $\mathrm{MgCl}_{2}$, and $0.48 \mu$ moles of Sky. After incubation $200 \mu \mathrm{g}$ of virions were taken into reaction mixture.

(4)-(7) Virions $(200 \mu \mathrm{g})$ were added to reaction mixture without preincubation of virions. curred only in Rug-Mg-RDV-RNA mixture, though the amount of sediment was much less than that of Rug-Mg-DNA mixture. In the case of Lut-Mg-RDV-RNA mixture, $\mathrm{OD}_{450}$ of the supernatant was decreased conspicuously, whereas $\mathrm{OD}_{260}$ was decreased not more than $10 \%$ of the original value, indicating that only $\mathrm{Lu}-\mathrm{Mg}$ complex, but not Lut-MgRDV-RNA, was precipitated by the centrifugation. No sediment was obtained from Sky-Mg-RDV-RNA mixture.

\section{Binding of $\mathrm{Mg}^{2+}$ to Sky}

Although Sky does not produce floccules with $\mathrm{Mg}^{2+}$, it is presumable

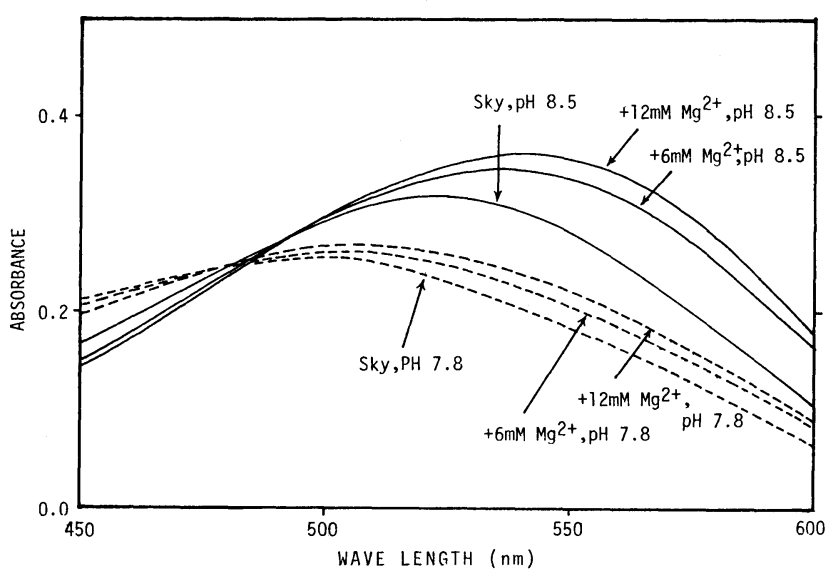

Fig. 3 Shift of absorption spectrum of skyrin with the addition of $\mathrm{Mg}^{2+}$. 


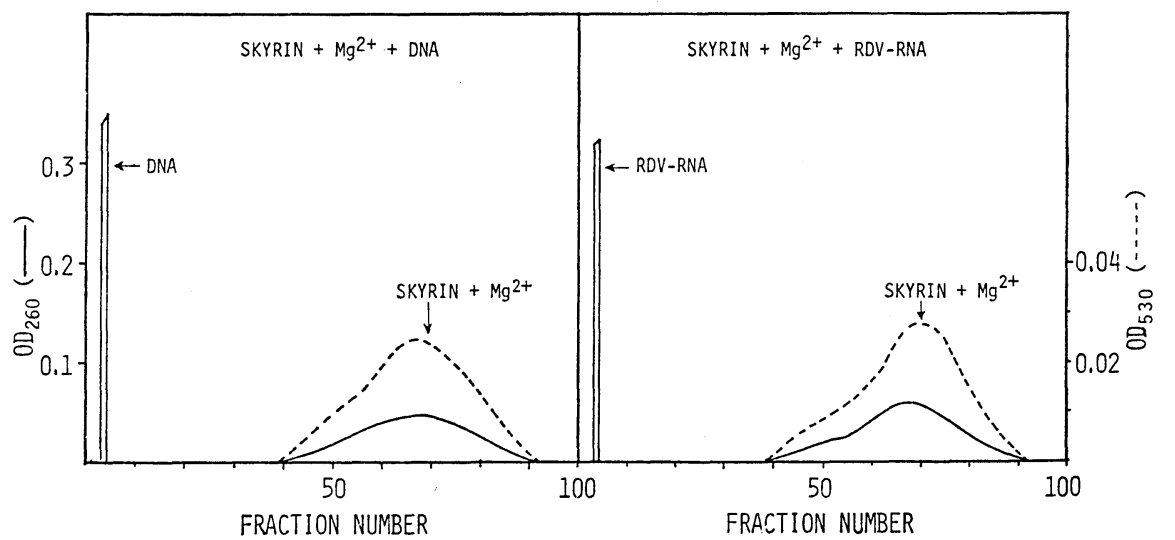

Fig. 4 Gelfiltration of the components of Sky-Mg-DNA and Sky-Mg-RDV-RNA mixtures on Sephadex G-25. Eluted with 0.1 M Tris-HCl, pH 8.5, containing $12 \mathrm{mM} \mathrm{MgCl}_{2}$.

from its chemical structure that Sky forms complex with $\mathrm{Mg}^{2+}$, and this is true because the absorption spectrum of Sky shifts to longer wave length with the increasing amounts of $\mathrm{Mg}^{2+}$ added (Fig. 3).

\section{Chromatographic Separation of Components in $S k y-M g-D N A$ and $S k y-M g-R D V-R N A$ Mixtures}

Sky-Mg-DNA and Sky-Mg-RDV-RNA mixtures in Tris- $\mathrm{HCl}(\mathrm{pH} 8.5)$ were incubated for $20 \mathrm{hr}$ at room temperature, then subjected to Sephadex G-25 column chromatography. $\mathrm{OD}_{260}$ and $\mathrm{OD}_{530}$ were measured for each $4 \mathrm{ml}$ eluent. Figure 4 indicates that DNA and RDV-RNA are completely separated from Sky-Mg complex, suggesting that Sky-Mg does not bind to DNA or RDVRNA in the mixture.

\section{Effect of Pretreatment of $R D V$-virions with} Sky on $R D V-R N A$ Transcriptase Activity The reaction mixture for assay of RDVRNA transcriptase activity contains RDVvirions as sources of dsRNA and transcriptase, i.e., the template RNA is not directly exposed to the reaction mixture but is enclosed in capsids. When virions are pretreated with Sky dissolved in $0.1 \mathrm{M}$ Tris- $\mathrm{HCl}$ ( $\mathrm{pH}$ 8.5) containing $\mathrm{Mg}^{2+}$, precipitated by centrifugation, and the precipitates are added to the reaction mixture, RDV-RNA transcriptase activity is not inhibited at all, whereas the addition of supernatant, which contains Sky, inhibits the activity conspicuously. Table 5 shows that the mere incubation of virions in Tris buffer, containing $\mathrm{Mg}^{2+}$, causes loss of activity by $38 \%$, possibly because of the release of RNA from virions. When this loss of activity by preincubation is taken into account, the Skytreated virions clearly retain their activity. The result suggests that Sky inhibits the transcriptase not by binding to RDV-RNA but by contacting virions at the site of RNA synthesis.

\section{DISCUSSION}

Lut is a well-known mycotoxin produced by Penicillium islandicum. On the basis of the spectral change of Lut, ${ }^{18}$ ) it was presumed that Lut bound in vitro with thymus DNA in the presence of $\mathrm{Mg}^{2+}$ to form a complex (DNA-Mg-Lut) with a molecular ratio of $4-6: 1: 1$. Subsequently, the DNA-Mg-Lut complex was isolated by gel filtration of SE Sephadex C-25 and the measurement of flow dichroism demonstrated that the orientation of the planar chromophore of Lut was parallel with the axis of DNA double-helix. The inhibitory effect of Lut on DNA-dependent RNA polymerase activity was demonstrated by Ueno et al. ${ }^{19)}$ and Senetac et al. ${ }^{20)}$ Lut also inhibits the DNA synthesis in vitro. Detailed review on the mode of action of Lut on nucleic acid metabolism is 
given by Enomoto and Ueno. ${ }^{21)}$

Regulosin is a kind of toxin produced by Endothia parasitica and has a biological activity similar to lut. ${ }^{22)}$ Sky is another pigment produced by the same fungus but is not toxic to mammals. ${ }^{23)}$

The purpose of this study is to seek some agents which inhibit the synthesis of viral RNA without inhibiting the functions of host cell DNA. From this view point, Lut and Rug are useless for the present purpose but are used to compare their modes of action on DNA and RDV-RNA with that of Sky because these are closely related with each other in their chemical structures.

The test for inhibitory effects of three pigments on RNA syntheses directed by $E$. coli DNA and RDV-RNA revealed that only Sky was satisfactory for the present purpose because this pigment inhibited only RDVRNA transcriptase but had no effect on $E$. coli RNA polymerase. Conversely, Lut and Rug inhibited $E$. coli RNA polymerase but inhibited not at all or only very slightly RDV-RNA transcriptase.

Above described effects appear to be correlated with the formation of pigment- $\mathrm{Mg}$ nucleic acid complexes which can be precipitated by centrifugation at $59,000 \times g$ for 20 min in cases of Lut and Rug, but are not in the case of Sky. The relationship can be seen in the following:

\begin{tabular}{|c|c|c|c|c|}
\hline & \multicolumn{2}{|c|}{$\begin{array}{c}\text { Inhibition of RNA } \\
\text { synthesis directed } \\
\text { by }\end{array}$} & \multicolumn{2}{|c|}{$\begin{array}{l}\text { Formation of } \\
\text { precipitable com- } \\
\text { plex with }\end{array}$} \\
\hline & $\begin{array}{l}\text { E. coli } \\
\text { DNA }\end{array}$ & RDV-RNA & $\begin{array}{l}\text { E. coli } \\
\text { DNA }\end{array}$ & RDV-RNA \\
\hline $\mathrm{Lut}+\mathrm{Mg}^{2+}$ & H & - & $H$ & - \\
\hline $\mathrm{Rug}+\mathrm{Mg}^{2+}$ & H & + & H & + \\
\hline $\mathrm{Sky}+\mathrm{Mg}^{2+}$ & - & H & - & - \\
\hline
\end{tabular}

Lut and Rug produce floccules immediately after the addition of $\mathrm{Mg}^{2+}$, whereas Sky does not. It is presumable that Sky forms complex with $\mathrm{Mg}^{2+}$ because of the spectral change. Results of chromatographic separation, using Sephadex G-25, of the components of Sky-Mg-DNA and Sky-Mg-RDV-RNA mixtures revealed that DNA and RDV-RNA are not bound to Sky in the presence of $\mathrm{Mg}^{2+}$.
RDV-virions pretreated with Sky in the presence of $\mathrm{Mg}^{2+}$ retained the transcriptase activity, whereas this was markedly inhibited by the addition of supernatant, which contains Sky. This suggests that the inhibition by Sky occurs not by its binding to RDVRNA but by contacting the virions at the site of RNA synthesis. Precise mechanism of action remains to be solved in future. It is not known why E. coli RNA polymerase is not inhibited by Sky in the presence of $\mathrm{Mg}^{2+}$.

In the case of reovirus, dsRNA is synthesized via single-stranded RNA which is produced by the transcription of dsRNA (see the scheme presented by Silverstein et $a l .{ }^{24}{ }^{\text {' }}$ If this is also the case with RDV, it is presumable that the synthesis of dsRDV-RNA will be inhibited by inhibiting the transcription of dsRNA with some agent. Our unpublished data revealed that when Sky, at $20-40 \mu \mathrm{g} / \mathrm{g}$ fresh weight, was administered to rice leaves detached from RDV-infected plants, together with ${ }^{32} \mathrm{P}$ and incubated at $25^{\circ} \mathrm{C}$ for $24 \mathrm{hr},{ }^{32} \mathrm{P}$-incorporation into dsRDVRNA was apparently decreased without decrease of ${ }^{32} \mathrm{P}$-incorporation into cell ribosomal RNA, whereas Rug at the same dosage decreased ${ }^{32} \mathrm{P}$-incorporation into both RNA's. Tests on the preventive effect of Sky on RDV-infection to rice plants and its therapeutic effect on RDV-infected plants are now in progress. Since Sky is an acidic pigment and hardly soluble in water, a problem remains to be solved as to how to stimulate its penetration and translocation to target tissues when applied to the leaf surface.

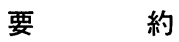

構造的に近縁な 3 種の系状菌生産色素ルテオスカイリ ン(Lut), ルグロシン (Rug), スカイリン (Sky) につい て,イネ萎縮病ウイルス (RDV) RNA 転写酵素打よび E. coli RNA ポリメラーゼに対する阻害勃果を，それ ぞれの in vitro 合成系を用いて比転した．Lut は E. coli RNA ポリメラーゼを強く阻害し，RDV-RNA 転写醋 素は阻害しない. Rug は前者を強く, 後者を弱く阻害す る. Sky は RDV-RNA 転军のみを阻害する. $\mathrm{Mg}^{2+}$ 存 在下で Lut, Rug は DNA と, Rug は RDV-RNA と も，複合体を作り，これは $59,000 \times g 20$ 分の遠心分離 
で沈殿する. Sky は DNA とも RDV-RNA とも $\mathrm{Mg}^{2+}$ 存在下で複合体を作らない. RDV 粒子を Sky と $\mathrm{Mg}^{2+}$ で前処理しても粒子は転写酵素活性を保持するが，これ に前処理液の上清（Sky を含む）を加えると活性は阻害 される，このことから，Sky は RDV-RNA と結合する ことなく，粒子の外にあって RNA 合成の場に接触して RNA 合成を阻害すると推論した。

\section{REFERENCES}

1) K. Mimura, I. Kimura \& N. Suzuki: Virology 28, 571 (1966)

2) T. Kodama \& N. Suzuki: Ann. Phytopath. Soc. Japan 39, 251 (1973)

3) T. Kodama, I. Kimura \& N. Suzuki: "Biochemical Regulation in Diseased Plants or Injury," Phytopath. Soc. Japan, p. 59, 1968

4) N. Suzuki, I. Kimura \& T. Kodama: Ann. Phytopath. Soc. Japan 39, 1 (1973)

5) M. Nakata \& N. Suzuki: Ibid. 41, 345 (1975)

6) M.I. Simon \& H. Van Vunakis: J. Mol. Biol. 4, 488 (1962)

7) B. Singer \& H. Fraenkel-Conrat: Biochemistry 5, 2446 (1966)

8) N. Suzuki: Botyu-Kagaku 35, 153 (1970)

9) I. Kimura: Ann. Phytopath. Soc. Japan 40, 208 (1974)

10) J. Marmur: J. Mol. Biol. 3, 208 (1961)

11) S. Shibata, O. Tanaka, G. Chihara \& H.
Mitsuhashi: Pharm. Bull. Japan 1, 302 (1973)

12) S. Shibata, T. Murakami, O. Tanaka, G. Chihara \& M. Sumimoto: Ibid. 3, 274 (1955)

13) S. Shibata, O. Tanaka \& I. Kitagawa: Ibid. 4, 143 (1956)

14) S. Shibata, T. Murakami \& M. Takido: Ibid. 4, 303 (1956)

15) Y. Ueno, A. Platel \& P. Fromageot: Biochim. Biophys. Acta 134, 27 (1967)

16) Y. Ueno, I. Ueno, K. Mizumoto \& T. Tatsuno: J. Biochem. 63, 395 (1968)

17) Y. Ueno, I. Ueno \& K. Mizumoto: Japan J. Exptl. Med. 38, 47 (1968)

18) T. Ohba \& P. Fromageot: Eur. J. Biochem. 1, 147 (1967)

19) Y. Ueno, I. Ueno \& T. Tatsuno: Seikagaku 38, 687 (1966)

20) A. Sentenac, A. Ruet \& P. Fromageot: Bull. Soc. Chim. Biol. 49, 247 (1967)

21) M. Enomoto \& I. Ueno: "Mycotoxins," ed. by I.F.H. Purchasw, Elsevier Amsterdam, p. 303, 1974

22) Y. Ueno, I. Ueno, N. Sato, M. Itoi, M. Enomoto \& H. Tsunoda: Japan. J. Exptl. Med. 38, 47 (1968)

23) H. Tsunoda: J. Food Hyg. Soc. Japan 2, 33 (1961)

24) S.C. Silverstein, C. Astell. J. Christman, H. Klett \& G. Acs: J. Virology 13, 740 (1974) 